\title{
Mălina CIOCEA*
}

\section{Book review of Mass-media, modernitate tendențială și europenizare în era Internetului [Mass-media, tendential modernity and Europeanization in the Internet era] by Constantin Schifirneț, Bucharest: Tritonic, 2014, 356 pages}

A strong voice in the Romanian sociology of communication, Constantin Schifirneț has published extensively in the fields of cultural anthropology and Romanian philosophical and sociological thinking, re-editing fundamental works by Spiru Haret (vol. I-XI, 2009-2010), C. Rădulescu-Motru, A.D. Xenopol and other significant authors. His most recent papers analyze phenomena and processes in Romanian society: modernization and Europeanization, with a special focus on the role played by mass-media in these developments.

This book gathers several articles and studies previously published in various academic journals, which illustrate the evolution of the central concept in professor Schifirneț's systematic investigation of contemporary Romania: tendential modernity. The author defines tendential modernity as "a specific type of development, mainly produced as a modern political and institutional construction in a non-modern social and economic context" (Introduction, p. 11). The concept is minutely articulated in chapter 14 of the present book, From tendential modernity to Europeanization. The analysis of mass-media impact on the Europeanization of Romanian national society requires an in-depth study on transition societies, where modernization is a political strategy, rather than an organic result of capitalist economy. Romanian modernity is defined by the author as "a tendency, rather than an evidence" (p. 286), a mosaic of organic cultural models and unstructured Western influences. Initially imported as a political project, modernity has failed to replace obsolete social structures and institutions. With capitalist culture, entrepreneurship and civil society missing, modernity in Romania does not permeate the deep strata of traditional culture: "there is modernity, but the modern man is missing" (p. 291). On this imperfect, incomplete process of modernization is now superimposed a new type of modernity, Europeanization, which requires a reorganization of nationhood. The author's constant preoccupation with processes of social change in Romania allows him to claim that "all discourses in Romanian public space invariably associate Europeanization with a new modernization, which shows the existence of a modernization deficit, which people expect to recover through European development" (p. 298). In the absence of organic assimilation of European values and modern behavior, Europeanization may well result in

* National University of Political Studies and Public Administration, Romania, malina.ciocea@comunicare.ro 
half-way modernization, dissociated from Romanians' real needs. In this context, mass media can model European behavior.

The author's interest in cultural practices is well illustrated by the article Traditional culture - mass media culture, initially included in the book Generation and culture, published in 1985. In fact, the author was one of the first researchers of mass media in Romania and its impact on various publics.

In the book reviewed here, the concept of tendential modernity is put to work in a variety of contemporary contexts. The articles approach cases such as: image of institutions in a tendential modernity society (chapter 7), corporate social responsibility in Romanian society (chapter 9), types of interactions on the forums of online newspapers (chapter 4), processes of interaction and socialization in mass media and new media (chapter 12). The most consistent part of the book is constituted by the cumulative development of the central concept. The earlier chapters fix the role played by mass media in the modernization process. In The paradox of the public space, the author points that mass media's capacity to model public space depends on the level of economic and social development and the complex value system. From the national public sphere, the perspective opens towards European public sphere (chapter 2), the main thesis developed by the author being that in post-communist societies, mass media favor party elites' viewpoints, rather than the opinion of various social groups. The following chapter discusses transformations in identitarian processes, in the context of Europeanization, delving into the early modernization stages. While the author's interest in $19^{\text {th }}$ century history places him into a well-established tradition in Romanian thought, it is his acute analysis of contemporary processes which is the real gain of the book. Questions such as: "Can mass media have a real influence in the process of Europeanization in the context of the population's distrust in other fundamental institutions?" (chapter 6, The Europeanization of national community in the context of tendential modernity, p. 123) could invite vivid debates about various distortions of modern imperatives in Romanian society. The presentation of complex research developed in the grant "The media construction of Europeanization as a public problem in the context of Romanian society's European integration" provides much-needed data on the Europeanization of local media (see, for instance, chapter 10, Europeanization, identity and mass-media in tendential modernity society on the content of news on public and private TV channels and the role of national public debates in the formation of European identity).

As knowledge about European identity and European public sphere progresses, such local analyses on "the domestication of Europeanization" will build an informed perspective about the national publics' expectations and reactions. On the other hand, they invite an unambiguous treatment of "the European man", who "is not an artefact, the consequence of constructed identity" (p. 188). 